\title{
Effectiveness of Wave of Shock Extracorporeal in Patients with Hallux Rigidus in the CCOI Frank País
}

 \\ ${ }^{1}$ Especialista de 1er Grado Medicina Física y Rehabilitación, Profesor Auxiliar e Investigador Agregado, Cuba \\ ${ }^{2}$ Especialista de 1er Grado Medicina Interna, Profesor Asistente e Investigador Agregado, Cuba \\ ${ }^{3}$ Especialista de 2do Grado Ortopedia y Traumatología, Profesor Titular e Investigador Titular, Cuba \\ *Corresponding author: Marisel Ibarbia Carreras, Especialista de 1er Grado Medicina Física y Rehabilitación, Profesor \\ Auxiliar e Investigador Agregado, Cuba
}

\begin{abstract}
ARTICLE INFO
Received: February 18, 2021

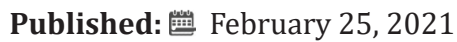

Citation: Marisel Ibarbia Carreras, Ernesto W Planas Montalvo, Luis Oscar Marrero Riverón. Effectiveness of Wave of Shock Extracorporeal in Patients with Hallux Rigidus in the CCOI Frank País. Biomed J Sci \& Tech Res 34(2)-2021. BJSTR. MS.ID.005516.
\end{abstract}

Keywords: Shock Waves; Forefoot; Hallux rigidus

\section{ABSTRACT}

Objective: To evaluate the effectiveness of therapy with waves of shock in the treatment of hallux rigidus.

Methods: Is conducted one study descriptive of cutting transverse, with 26 patients with hallux rigidus, treated with waves of shock Extracorporeal in the complex Scientific Orthopedic International "Frank Country", in the period ranging from March 2019 until February of 2020. performed the analysis of the variables (age, sex, pain and the American Orthopedic Foot \& Ankle Society scale). They are obtained the frequencies absolute and relative. With them they were concocted the tables that summarize the data statistics of the research.

Results: predominated the sex female $84.6 \%$ and $38.5 \%$ (50-60 years of age). The number of patients according to the classification of Coughlin $(65.3 \%)$ belonged to the grade I and all had pain before the application of the therapy. Then of the treatment this situation was reversed and $69.2 \%$ of patients ceased to feel, keeping in $7.7 \%$ of cases (grade III and IV). The scale of American Orthopedic Foot \& Ankle Society (53.8\%) of the patients studied, had one interpretation qualitative poorly $(<50$ points) before starting the treatment; subsequently, only $7.7 \%$ remained with that score.

Conclusion: The therapy with waves of shock, with the team Well Wave, had one high effectiveness and allowed one quick recovery of patients and their incorporation into the activities daily.

\section{Introduction}

Hallux rigidus is a deformity in the joint located in the base of the first finger. "Hallux" it refers to the first toe of the foot, while that "Rigidus" indicates a stiffness in the finger that prevents the movement. Hallux rigidus is the, in reality, a form of arthritis degenerative [1]. It was described for the first time by Davies-Colley in 1887, [2] who 's named as Hallux Flexus, and more later Coterill [3] coined the term Hallux rigidus is the term most used in the present. However, it is also known as Hallux Limitus, metatarsus primus elevatus, dorsal bunion, Hallux Equinus, Hallux Dolorosus, and metatarsus non extensus. It is more common in the adult, in which present changes osteoarthritic degenerative widespread that increase with age. Presents prevalence by sex women and up to two thirds of patients have history familiar positive for this disease [4]. This condition can cause discomfort and even disability, and that this important finger is used for walking, bending, climbing and even to keep up. Clinically, the typical presentation consists of pain and stiffness of the metatarsophalangeal joint with the presence of predominantly dorsal osteophyte formation. The signs and symptoms early include:

A. Pain and stiffness of the finger fat when they are used (to the walking, keep on standing, leaning, among others)

B. Pain and stiffness intensified by cold or humidity 
C. Difficulty to perform certain activities (running, stooping)

D. Swelling and inflammation around the joint $\mathrm{A}$ as the disease worsens, may develop the following symptoms further:

E. Pain, even during the break

F. Difficulty to use footwear, because they develop spurs (overgrowth) in the bone

G. Pain continued in the hip, the knee or hand down the back due to changes in the mode of walking

H. In severe cases, lameness [5]

I. In its stage's primary, the mobility of the finger fat only find something limited; then it is called "Hallux Limitus ". But as the problem progresses, the range of movement of the finger decreases until reaching the state final "Rigidus" which is when the finger remains stiff or as "frozen "[4].

J. In the literature is described four degrees as the classification of Coughlin: [6]

K. Grade 0, the dorsiflexion of the first metatarsophalangeal is between 40 and 60 degrees (loss of $20 \%$ of normal mobility), without clinical or radiographic alterations.

L. Grade I, the dorsiflexion is located between 30 and 40 degrees and appreciate osteophytes lats, but with minimal narrowing joints.

M. Grade II, dorsiflexion is between 10 and 30 degrees, there are periarticular osteophytes, a moderate flattening of the metatarsal head with sclerosis or narrowing of the joint interline.

N. Grade III dorsiflexion is less than 10 degrees. In addition, there are severe radiographic changes, with cysts or erosions, irregular or hypertrophic sesamoids, and constant pain especially in the last degrees of movement.

0. Grade IV, there is a disappearance of the joint interline, with free bodies, and pain in the entire range of motion. In general, Hallux rigidus is the result of degenerative processes caused by various conditions such as: trauma, accumulated microtrauma, secondary to eccentric loading, systemic diseases, dissecting osteochondritis and infection.

As will progress the degeneration articular occur changes in the periosteum, synovium and capsule particularly which generate one clamping base of the phalanx proximal or portion Dorsal head of the metatarsal with dorsiflexion forced producing lesions chondral or osteochondral of the cartilage articular and of the metatarsal head with erosion and formation of osteophytes. While proliferate the osteophytes, the joint is becoming more prominent and the arches of mobility are more limited due to a pinched back. The pain is secondary to the movement of the joint surfaces degenerate, to the impingement of osteophytes during the dorsiflexion and retraction of the synovial swollen, and as the nerves digital and capsule [7]. The rays $\mathrm{X}$ can be entirely normal or show destruction articular severe. The changes radiological not necessarily correspond to the symptomatology. However, in the projection dorsoplantar is can observe reduction of the space and osteophytes lateral and medial, the injuries osteochondritis also be seen better in the projection anteroposterior. The projection side can see the osteophytes ridges and bodies free, as well as the decrease of the space joint [8].

At the present time they are have described various treatments, although the evidence scientific still is scarce $[4,9]$ is recommended treatments conservative so initial (as the state of articulation and demand of the patient). This consists of a non- steroidal anti inflammatory plan, kinesiology, cryotherapy (application of local ice), modification of certain activities and the change of footwear and the use of insoles with metatarsal discharge for a period of approximately 6 months [9]. If the pain and stiffness persist, the treatment surgical by arthroscopy, surgery percutaneous or minimum access is indicated after the failure of the treatment conservative, so the same if the patient comes with hallux rigidus grade II grade III or IV, is indication of surgery. The procedures surgical are elected in accordance with the needs and expectations of the patient and the experience of the surgeon with a period approximately of recovery six weeks [10]. However, before this method invasive, in the present it is recommended first to treat the lesion with waves of shock extracorporeal [11]. The application of this therapy has proven to be safe and effective; in other pathologies, surgical procedures have been avoided $[12,13]$. The goal of therapy by waves of shock extracorporeal, is relieve pain, improve the mobility and stability.

In the Complex Scientific Orthopedic International "Frank País" is used the equipment Well Wave from the end of the year 2013 as a method of treatment of pain chronic in those patients who do not improve with other treatments conservatives. The unit of treatment produces, by a source piezoelectric external, waves sound of high energy. The number of patients who have received treatment Physiotherapeutic with waves of shock by this cause has increased in the recent years in the institution with results satisfactory. This research was conducted with the objective of evaluating the effectiveness of therapy with waves of shock in the treatment of hallux rigidus.

\section{Methods}

It was conducted one study descriptive of cutting cross, with patients who suffer from Hallux rigidus. For treatment therapy is used the equipment Well Wave (wave of shock extracorporeal), in the Complex Scientific Orthopedic International "Frank País", in the period ranging from March 2019 to February 2020. The selection of patients in the sample were He performed by one sampling of convenience and it was integrated by 26 cases. To determine the effectiveness (real benefit), the medical and physiological effects that occur when applying this therapy were analyzed. The criteria 
for inclusion were patients of both sexes, older than 18 years old, with inability to put on with normal and patients with retention of pain in one period of six months or more; as well as the patients who received at the least, three of the following treatments: Drugs inflammatories, laser therapy, ultrasound therapy magnetotherapy, supports.

Criteria for exclusion

A. Patients who refuse to continue in the study

B. Patients with diseases chronic decompensated (alterations cardiovascular severe, conditions neurological)

C. Patients with disorders of coagulation

D. Pregnant patients

E. Patients with polyneuropathies

F. Patients with Epiphysiolysis

G. Patients with pacemakers

H. Patients with tumors malignant primary or metastatic

I. Patients with acute or chronic infections of the tissues

J. Patients with severe arthritic changes

In all the patients in consultation initial they were made one detailed examination, examination physical, study Radiographic lateral view and anterior posterior forefoot. A time that was the diagnosis clinical radiology of the Hallux rigidus and taking into account that the patient had used other methods conservative and not had presented improvement, he began with the treatment therapy of waves of shock extracorporeal on the first knuckle of foot affection with the equipment Well Wave, constituted by a source of waves of shock piezo. In all the patients they were asked for their consent informed to participate in the study.

\section{Procedure}

A. Patient lying in supine supine on one stretcher

B. Location of the painful point by palpation and lubrication of the area of treatment gel on the skin and in the membrane of coupling of the computer for transmission of waves of shock

C. Density of energy from $0.048 \mathrm{mj} / \mathrm{mm} 2$ to $0.110 \mathrm{mj}$ / mm2. Application progressive of waves of shock to low intensity, according tolerance
D. Frequency $0-8 \mathrm{~Hz}$
E. Maximum pressure: 7 to $49 \mathrm{Mpa}$
F. Depth of penetration: 0 to $30 \mathrm{~mm}$
G. Sessions: 3 to 5 (1 time per week)
H. Duration of treatment: 15 to $20 \mathrm{~min}$
I. No sedation or analgesics

The patients were evaluated by the authors of this research, before and after of the treatment, in two times to the month and the three months ended the therapy. It took in account the following: variables age, sex and scale analog visual (EVA) 10 points. It is applied also the scale American Orthopedic Foot and Ankle Society (AOFS) of the forefoot, as is shown in the Appendix 1. In spite of being a scale used to assess to the patient one time which makes the treatment surgical, was used because it is one scale quite complete and that you can assess the metatarsals, the joints metatarsal phalangeal and joints interphalangeal proximal, with a score maximum is 100 points. This scale includes three dimensions (pain, function, and alignment). The global score is obtained from the sum of the scores obtained in each of the three dimensions: pain (maximum of 40 points), function (maximum of 45 points) and alignment (maximum of 15 points). A higher score is referred to better state functional, for your best interpretation the authors proposed criteria for interpreting qualitative the results in $<50$ points: bad, 51-70 points: regular, 71-90 points: good,> 91 points: excellent

\section{Criteria for Evaluation of Response to the Treatment}

Good Evolution: when there is remission of pain (VAS-0), restoration of joint mobility and incorporation of patients to their usual activities.

Regular Evolution: when there is a noticeable improvement in pain (VAS $\leq 3$ ), improvement in joint range of motion, requirement of some conservative treatment and incorporation to normal activities.

Evolution Bad: when there was no remission of pain (VAS> 3), no improvement in the mobility and not incorporating the activities usual. It requires surgery.

The processing of information is performed in EXCEL and by the package statistical SSPS 11.5. Is performed the analysis of frequency of the variables referred to in the study and obtained the frequencies absolute and relative. Similarly, it made the Test Ji square of independence to determine the existence of differences statistically significant between the proportions obtained. Is indicated, in each case the value corresponding to the probability of occurrence p; an alpha error of 0.05 and a confidence of $95 \%$ were prefixed. It was determined, as region critical or rejection, when the value associated to $\mathrm{p}$ was less than 0.05 and, in such case, is rejected the hypothesis null of independence and concluded that the variables were dependent among themselves.

\section{Ethical Considerations}

The study was conducted following the principles ethical contained in the Declaration of Helsinki [14]. The Committee of Ethics for research in human, of the Complex Scientific Orthopedic International "Frank País", ensured by the fulfillment of these requirements and approved the research. The information obtained is handled on a confidential and only was used for purposes research. Not reveal the identity of people. 


\section{Results}

As can be seen in the Table 1 in the sample there was a predominance of the sex female with 22 patients $(84.6 \%)$ of the group age of $50-60$ years (38.5\%). With a femininity ratio of 5.5 in which there are around 5 sick women for every sick man in the place and period studied. In the Table 2 is analyzed the number of patients according to the classification of Coughlin, in which belonged to the grade I $65.3 \%$ of patients treated. Only he is found in the sample studied by $3.8 \%$ in the grade 0 , belonging to the sex male. In the grade III and IV with $7.7 \%$ each one, of both sexes. As can observe in the Table 3, the totality of the patients he had pain before the application of the wave of shock, was indication principal for the realization of this technique not invasive. After of the treatment this situation is reversed favorably because $69.2 \%$ of the patients did not have pain. Only $7.7 \%$ presented pain in the march, coinciding also two patients (7.7\%) with pain in the rest. It noted that were patients that were found in the degree III and IV on the scale of Coughlin. In the Table 4 can see the results with the scale of AOFS. They reached a qualitative interpretation of bad $(<50$ points) $53.8 \%$ of the patients studied, before starting the treatment. After the performed five sessions of therapy with waves of shock, according to the procedure described, $53.8 \%$ and $30.8 \%$ of patients reached results of excellent and good, respectively. Only two cases $(7.7 \%)$ remained with a regular score (51-70) and also two patients (7.7\%) with a low score of 50 points. At the same time, it coincided that they belonged to grade III and IV on the Coughlin scale.

Table 1: Pacientes con Hallux rigidus según edad y sexo.

\begin{tabular}{|c|c|c|c|}
\hline Grupos de edad & $\begin{array}{c}\text { Femenino } \\
\text { No. (\%) }\end{array}$ & $\begin{array}{c}\text { Masculino } \\
\text { No.(\%) }\end{array}$ & $\begin{array}{c}\text { Total } \\
\text { No. (\%) }\end{array}$ \\
\hline De 40-50 años & $4(15.4 \%)$ & $2(7.7 \%)$ & $6(23.1 \%)$ \\
\hline De 51-60 años & $9(34.6 \%)$ & $1(3.8 \%)$ & $10(38.5 \%)$ \\
\hline De 61-70 años & $6(23.1 \%)$ & $1(3.8 \%)$ & $7(26.9 \%)$ \\
\hline Más de 71 años & $3(11.5 \%)$ & $0(0 \%)$ & $3(11.5 \%)$ \\
\hline Total & $22(84.6 \%)$ & $4(15.3 \%)$ & $26(100 \%)$ \\
\hline
\end{tabular}

Table 2: Pacientes con Hallux rigidus según clasificación de Coughlin.

\begin{tabular}{|c|c|c|c|}
\hline $\begin{array}{c}\text { HALLUX } \\
\text { RIGIDUS }\end{array}$ & $\begin{array}{c}\text { Femenino } \\
\text { No. (\%) }\end{array}$ & $\begin{array}{c}\text { Masculino } \\
\text { No.(\%) }\end{array}$ & $\begin{array}{c}\text { Total } \\
\text { No. (\%) }\end{array}$ \\
\hline GRADO 0 & $0(0 \%)$ & $1(3.8 \%)$ & $1(3.8 \%)$ \\
\hline GRADO I & $16(61.5 \%)$ & $1(3.8 \%)$ & $17(65.3 \%)$ \\
\hline GRADO II & $3(11.5 \%)$ & $1(3.8 \%)$ & $4(15.3 \%)$ \\
\hline GRADO III & $2(7.7 \%)$ & $0(0 \%)$ & $2(7.7 \%)$ \\
\hline GRADO IV & $1(3.8 \%)$ & $1(3.8 \%)$ & $2(7.7 \%)$ \\
\hline Total & $22(84.6 \%)$ & $4(15.3 \%)$ & $26(100 \%)$ \\
\hline
\end{tabular}

Table 3: Pacientes con Hallux rigidus, según escala visual analógica, antes y después del tratamiento.

\begin{tabular}{|c|c|c|c|c|}
\hline \multirow{2}{*}{ Escala Visual Analógica } & \multicolumn{2}{|c|}{ Antes } & \multicolumn{2}{c|}{ Después } \\
\cline { 2 - 5 } & FA & $\%$ & FA & $\%$ \\
\hline Sin dolor & 0 & 0 & 18 & 69.2 \\
\hline
\end{tabular}

\begin{tabular}{|c|c|c|c|c|}
\hline Dolor en actividades intensas & 4 & 15.3 & 4 & 15.3 \\
\hline Dolor a la marcha & 9 & 34.6 & 2 & 7.7 \\
\hline Dolor en reposo & 13 & 50.1 & 2 & 7.7 \\
\hline
\end{tabular}

Table 4: Pacientes con Hallux rigidus, según Escala de AOFS, antes y después del tratamiento.

\begin{tabular}{|c|c|c|c|c|}
\hline \multirow{2}{*}{ Escala AOFS } & \multicolumn{2}{|c|}{ Antes } & \multicolumn{2}{c|}{ Después } \\
\cline { 2 - 5 } & FA & \% & FA & \% \\
\hline Excelente $(>90)$ & 0 & 0 & 14 & 53.8 \\
\hline Bueno (71-90) & 1 & 3.8 & 8 & 30.8 \\
\hline Regular (51-70) & 11 & 42.3 & 2 & 7.7 \\
\hline Malo $(<50)$ & 14 & 53.8 & 2 & 7.7 \\
\hline
\end{tabular}

In the Table 5 shall appreciate the analysis of the criteria for evaluation of response to the treatment, in which the results good and regularly are considered satisfactory and bad, unsatisfactory. There was a higher percentage of satisfactory results at the end (50\%), when re-evaluating at three months there was an increase $(69.2 \%)$. Only $15.4 \%$ of the evaluating to three months completed the therapy had one response bad, coinciding with that found in the grade III and IV according to the classification Coughlin, at which contributed to the therapy does not result, persisting pain and functional limitation.

Table 5: Criterios de evaluación de la respuesta al tratamiento dado a los pacientes.

\begin{tabular}{|c|c|c|c|c|c|c|}
\hline $\begin{array}{c}\text { Criterios de Evaluación } \\
\text { de la Respuesta al } \\
\text { Tratamiento }\end{array}$ & FA & \% & Mes & \% & $\begin{array}{c}\text { Tres } \\
\text { Meses }\end{array}$ & \% \\
\hline Buena & 13 & 50 & 16 & 61.5 & 18 & 69.2 \\
\hline Regular & 8 & 31 & 6 & 23.1 & 4 & 15.4 \\
\hline Mala & 5 & 19.2 & 4 & 15.4 & 4 & 15.4 \\
\hline TOTAL & 26 & 100 & 26 & 100 & 26 & 100 \\
\hline
\end{tabular}

\section{Discussion}

According to the literature reviewed, the Hallux rigidus is more common in the adults for over 50 years old of age, predominating in the sex feminine [4]. This coincided with the studio that presents. It is described that degenerative arthritic changes increase with age Coughlin and Shurnas indicate that, when are still to patients with hallux rigidus during one period of time long, more than $80 \%$ can develop plus one symptomatology bilateral [6]. There are multiple classifications described by Regnauld, [7] Hattrup and Johnson, [15] Núñez -Samper [5] with wide interobserver variability, but perhaps the most complete and applicable is the one developed by Coughlin and Shurnas in 2003, [6] coinciding with this study. According to Deland JT and others, pain is a symptom common in this condition and may be present in the totality of cases [16]. This result was able to corroborate in the research that shows. Pain referred by the patient is presented to the force the dorsiflexion and the deflection side of the hallux. The pain in one home only appears at the end of the dorsiflexion can occur in the medium tour of the range of mobility. If progresses, it also affects the bending plant and finally 
to all the mobility, coming to produce pain constant, even in the rest, which makes it difficult to improve the treatment conservative conventional before described, however the use of waves of shock Extracorporeal, the patients evolved favorably, these are able to pass through the tissues and trigger phenomena of absorption, reflection, refraction and transmission of energy (effect direct). The negative phase is the cause of the indirect effects on the cellular tissue. The reversal of the inflammation chronic is another of the advantages of the use of the waves of shock Extracorporeal, since this inflammation persistent need of few components (called mast cells), whose activity increases with the waves acoustic, allowing the production of chemokines and cytokines that improve the inflammatory process.

To assess the results of surgical techniques, the American Society for Orthopedic Surgery, known as AOFAS for its acronym in English, uses the questionnaire designed by Kitaoka published in 1994 [17,18]. Its maximum score is 100 points. It is made up of three dimensions: pain, function, and alignment. A Although it is a tool used to evaluate the results after one surgery, in this study was useful also because with him is able to evaluate the various dimensions of the well - being related to health. Is an instrument specific that enables to detect the changes clinical of interest in the condition of patients, it allows evaluate functionally the joint metatarsophalangeal of the first toe of the foot and the quality of life of patients. In the reviewed literature, there are multiple articles that discuss the treatment of Hallux rigidus, dividing it into conservative and surgical [19-21]. However, no there are items original related to the treatment of hallux rigudus with this team in private. There are items like in which the authors agree that this therapy is effective in the treatment of tendinitis calcified of shoulder or another location, tendinopathy degenerative (tendinosis sleeve rotator, patellar, quadriceps, yarrow), epicondylitis, fascitis plantar trochanteritis, pseudoarthrosis, osteonecrosis and myofascial syndrome (does not include fibromyalgia) [11-13] due to their biological effects. When it applies this treatment, it occurs at the point of application one increase of formation of vessels blood by micro rupture of capillaries of tendon and bone. The increase of traffic in the area will allow the arrival of factors of repair tissue and oxygen, which will favor one recover more quickly.

Ago so that restore the process of healing, which in many cases. In the processes chronic, have been stopped or enlentecidos, causing, in addition, one response inflammatory initial, which gets one effect analgesic, accelerator of the metabolism and revascularization area [22]. The success of the treatment in this study in particular is achieved by the cooperation of patients, and it needs to locate the most painful point in the area treated. On the one hand, there is an individual tolerance to pain that is variable and individual to each person. This makes that the processes that for a patient are very painful, for others are not both. When the point of pain primary is eliminated by the effect analgesic of the wave of shock, appear other points that have been superimposed by the main pain. The more stitches disappear, the more effective the treatment, until their total remission. Such is the case that remained patients not improved after applying said therapy corroborating the literature reviewed; in which to patients who are in the grade III and IV is necessary realizable treatment surgical [10] (Annexure 1).

\section{Conclusion}

The therapy with waves of shock an important condition that can cause discomfort and even disability but is treated properly, with the team Well Wave, had one high effectiveness, which allowed one quick recovery of patients, their addition to the activities daily and improved their quality of life.

\section{Contribution of the Authors}

Marisel Ibarbia Carreras. General conception, research design and writing of the document, Ernesto W. Planas Montalvo. Analysis and interpretation of the study data and Luis Oscar Marrero Riverón. Corrections to the document and execution of the statistical analysis.

\section{References}

1. Asunción J, Martín X (2017) Hallux rigidus: etiología, diagnóstico, clasificación y tratamiento. Rev Esp Cir Ortop Traumatol 54: 321-328.

2. Davies Colley N (1887) Contraction of the metatarsophalangeal joint of the great toe (hallux flexus). Br Med J 1: 728.

3. Cotterill JM | (1888) Stiffness of the great toe in adolescents. Br Med J 1: $1158-1162$

4. Herrera Pérez M, Andarcia Bañuelos C, De Bergua Domingo J, Paul J, Barg A, et al. (2014) Propuesta de algoritmo global de tratamiento del Hallux rigidus según la medicina basada en la evidencia. Rev Esp Cir Ortop Traumatol 58(6): 377-865.

5. Nuñez Samper P (2015) Clasificaciones del hallux rígidus ¿todos vemos lo mismo? Rev Pie Tobillo 29(1): 22-26

6. Coughlin MJ, Shurnas PS (2003) Hallux Rigidus: Demographics, etiology and radiographic assessment. Foot Ankle Int 24: 731-43.

7. Regnauld B (1986) Hallux rigidus. Foot 335: 350.

8. Feldman KA (1992) The Green-Watermann procedure: geometric analysis and preoperative radiographic template technique. J Foot Surg 31: 182-185.

9. Álvarez F, Viladot R (2010) Hallux rigidus Algoritmo de tratamiento. En: Tratado de cirugía del antepié. Euromedice-Badalona 97-98.

10. Cabestany Castellá M, Cabestany Perich B, Castillo Sánchez L, Galaz López RE, Herrera Segura R, et al. (2017) Cirugía Mínimamente Invasiva Del Pie Barcelona: Editorial Glosa SL.

11. Romero M, Martínez A (2015) Alcances de la terapia con ondas de choque extracorpóreas en lesiones músculo-esquéleticas. Archivos Venezolanos de Farmacología y Terapéutica 34(2): 27-30.

12. Garcés J (2016) Eficacia de la terapia de ondas de choque como alternativa de tratamiento en lesiones del manguito rotador 13(1): 2329.

13. Schmitz C, Császár NBM, Milz S, Schieker M, Maffulli N, et al. (2015) Efficacy and safety of extracorporeal shock wave therapy for orthopedic conditions: A systematic review on studies listed in the Pedro database. Br Med Bull 116(1): 1-24.

14. Christie B (2000) Doctors revise Declaration of Helsinki. British Medical Journal 321: 913 
15. Hattrup SJ, Johnson KA (1988) Subjective results of Hallux rigidus following treatment with cheilectomy. Clin Orthop Relat Res 226: 182191.

16. Deland JT, Williams BR (2012) Surgical management of Hallux rigidus. J Am Acad Orthop Surg 20(6): 347-358.

17. Kitaoka HB, Alexander IJ, Adelaar RS, Nunley JA, Myerson MS, et al. (1994) Clinical rating systems for the ankle-hindfoot, midfoot, hallux and lesser toes. Foot \& Ankle International 15(7): 349-353.

18. Shields NN (2008) Hallux rigidus. Orthopaedic knowledge update: Foot and Ankle 4, EUA: AAOS.

19. Nagy MT, Walker CR, Sirikonda SP (2014) Second-generation ceramic first metatarsophalangeal joint replacement for Hallux rigidus. Foot Ankle Int 35: 690-698.

\section{ISSN: 2574-1241}

DOI: 10.26717/BJSTR.2021.34.005516

Marisel Ibarbia Carreras. Biomed J Sci \& Tech Res

(C) This work is licensed under Creative

Submission Link: https://biomedres.us/submit-manuscript.php
20. Baumhauer JF, Singh D, Glazebrook M, Blundell C, De Veris, et al. (2016) Prospective, randomized, multi-centered clinical trial assessing safety and efficacy of a synthetic cartilage implant versus first metatarsophalangeal arthrodesis in advanced Hallux rigidus. Foot Ankle Int 37: 457-469.

21. Méndez Gil A, Poggio D, Asunción J (2015) Osteotomía oblicua distal del primer metatarsiano en la cirugía del Hallux rigidus Valoración radiológica del descenso y acortamiento. Rev del Pie y Tobillo 29(2): 8893.

22. Mirallas Martínez JA (2005) Efectividad de las ondas de choque extracorpóreas basada en la evidencia. Rehabilitación (Madr) 39(2): 5258.

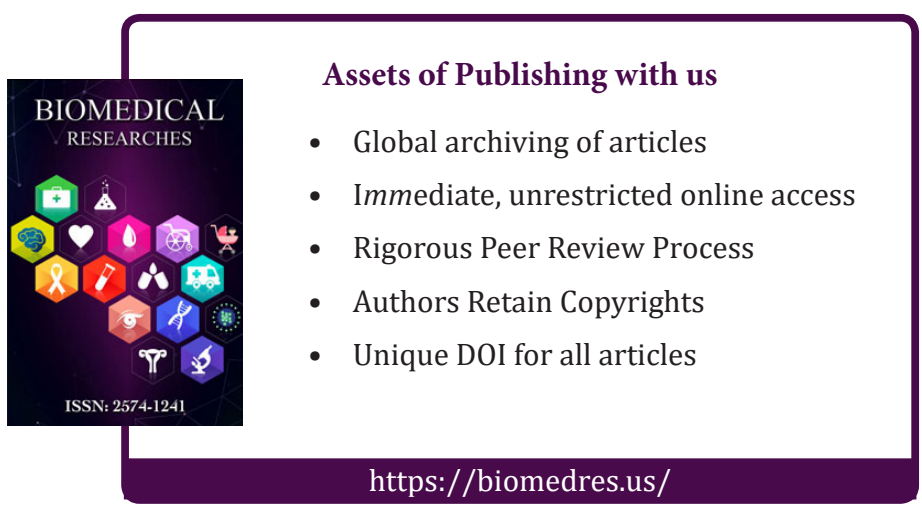

